\title{
Molecular characterization of hepatitis $C$ virus in liver disease patients in Botswana: a retrospective cross-sectional study
}

Lynnette Bhebhe ${ }^{1,2}$, Motswedi Anderson', Sajini Souda ${ }^{3}$, Wonderful T. Choga ${ }^{1,2}$, Edward Zumbika ${ }^{2}$, Zachary M. Shaver ${ }^{1}$, Tshepiso Mbangiwa ${ }^{1,4}$, Bonolo B. Phinius ${ }^{1}$, Chabeni C. Banda', Pinkie Melamu', Rosemary M. Musonda ${ }^{1,5}$, Max Essex ${ }^{1,5}$, Jason T. Blackard ${ }^{6}$, Sikhulile Moyo ${ }^{1,5}$ and Simani Gaseitsiwe ${ }^{1,5^{*}}$

\begin{abstract}
Background: Hepatitis C virus (HCV) infection is a major cause of chronic liver disease globally. Direct acting antivirals (DAAs) have proven effective in curing HCV. However, the current standard of care (SOC) in Botswana remains PEGylated interferon-a (IFN-a) with ribavirin. Several mutations have been reported to confer resistance to interferon-based treatments. Therefore, there is a need to determine HCV genotypes in Botswana, as these data will guide new treatment guidelines and understanding of HCV epidemiology in Botswana.

Methods: This was a retrospective cross-sectional pilot study utilizing plasma obtained from 55 participants from Princess Marina Hospital in Gaborone, Botswana. The partial core region of HCV was amplified, and genotypes were determined using phylogenetic analysis.

Results: Four genotype $5 \mathrm{a}$ and two genotype $4 \mathrm{v}$ sequences were identified. Two significant mutations - K10Q and R70Q - were observed in genotype 5 a sequences and have been associated with increased risk of hepatocellular carcinoma (HCC), while R70Q confers resistance to interferon-based treatments.

Conclusion: Genotypes $5 \mathrm{a}$ and $4 \mathrm{v}$ are circulating in Botswana. The presence of mutations in genotype 5 suggests that some patients may not respond to IFN-based regimens. The information obtained in this study, in addition to the World health organization (WHO) recommendations, can be utilized by policy makers to implement DAAs as the new SOC for HCV treatment in Botswana.
\end{abstract}

Keywords: Hepatitis C virus, HCV, Genotypes, Mutations, DAA, Botswana

\section{Background}

Viral hepatitis is the seventh leading cause of death globally [1], and hepatitis $\mathrm{C}$ virus (HCV) is one of the leading causes of liver failure. The prevalence of HCV differs by geographical location. In Africa, a range in prevalence from 1.7 to $14.7 \%$ has been reported [2-5]. In Botswana, preliminary studies reported a low HCV seroprevalence of below 1\% [6-8] although Botswana is endemic for both human immunodeficiency virus (HIV) and hepatitis B

\footnotetext{
* Correspondence: sgaseitsiwe@bhp.org.bw

${ }^{1}$ Botswana Harvard AIDS Institute Partnership, Research Laboratory,

Gaborone, Botswana

${ }^{5}$ Department of Immunology and Infectious Diseases, Harvard T.H. Chan

School of Public Health, Boston, MA, USA

Full list of author information is available at the end of the article
}

virus (HBV) with the prevalence of HIV/HBV co-infection ranging from 4 to $10.6 \%[6,7]$.

Treatment of HCV has evolved rapidly with the introduction of direct acting antivirals (DAA) in the last decade. DAAs can achieve sustained virologic responses (SVR) of 95 to 100\% [9], have shortened treatment duration, and have overcome many challenges faced by administering interferon-based regimens. The World health organization (WHO) has recommended that DAA regimens be used for HCV treatment, and the choice of antiviral therapy and duration of treatment of the DAAs are dependent on HCV genotype. Therefore, studies of circulating $\mathrm{HCV}$ genotypes are important prior to widescale treatment rollout [10]. In Botswana, there are no data on $\mathrm{HCV}$ genotypes. This study aimed to determine the HCV 
genotypes circulating in Botswana and to identify clinically relevant mutations within the $\mathrm{HCV}$ core region.

\section{Methods}

This is a retrospective cross-sectional pilot study utilizing 55 stored plasma samples collected between February 2015 and July 2016 from 55 liver disease patients at the liver clinic of Princess Marina Hospital, a referral hospital in Gaborone, Botswana. The study was conducted at Botswana Harvard AIDS Institute Partnership.

$\mathrm{HCV}$ ribonucleic acid (RNA) was extracted using the Qiagen Viral RNA kit using $140 \mu \mathrm{l}$ plasma samples according to the manufacturer's specifications (Qiagen, Hilden, Germany). The extracts were stored at $-80^{\circ} \mathrm{C}$ prior to genotyping. Amplification targeted the partial core region with two primer sets - outer core primers (5' - ACT GCC TGA TAG GGT GCT TGC - 3', nt $288 \rightarrow 308$ and $5^{\prime}$ - ATG TAC CCC ATG AGG TCG GC $-3^{\prime}$, nt $\left.732 \leftarrow 751\right)$ and inner core primers $\left(5^{\prime}-\right.$ AGG TCT CGT AGA CCG TGC A - 3', nt $321 \rightarrow 339$ and $5^{\prime}$ - CAT GTG AGG GTA TCG ATG AC - 3', nt $705 \leftarrow 724)$ previously described, $[11,12]$ relative to the H77 reference [13]. Nested PCR was carried out using Superscript (III) one-step RT-PCR with Platinum Taq DNA polymerase high fidelity kit (Invitrogen, USA) according to the manufacturer's instructions. PCR products were visualized on $1.5 \%$ agarose gel stained with ethidium bromide, and the positive amplicons were purified using the ZR DNA sequencing clean up kit (Zymo, Irvine, CA, USA) according to the manufacturer's specifications. Population sequencing was conducted using BigDye Terminator version 3.0 kit (Applied Biosystems; Foster City, CA, USA) sequencing chemistry on a 3130XL ABI genetic analyser (ABI PRISM 3130XL; Applied Biosystems).

Sequence files were edited using Sequencher version 5.0 software (Gene Codes Corp., Ann Arbor, MI, USA). Phylogenetic analysis was used to evaluate $\mathrm{HCV}$ genotypes and included reference sequences from the Los Alamos HCV sequence database (https://hcv.lanl.gov/content/index). Sequences were aligned in Clustal X version 2.1. Additional phylogenetic inference was conducted using the Bayesian Markov chain Monte Carlo (MCMC) in the Bayesian Evolutionary Sampling Trees (BEAST) version 1.7.5 as described previously $[8,14]$. Posterior probabilities $>80 \%$ were deemed statistically significant. Sequences were exported to BioEdit software where nucleotide sequences were translated to amino acids. H77 (accession number AF009606 [13]) served as the reference sequence, and mutations were visually analysed per amino acid position. Importantly, $\mathrm{H} 77$ is a genotype 1a reference; therefore, several genotype 1 references together with genotype 4 and 5 reference sequences were included in the analysis to distinguish between polymorphic regions that differ by genotype and
Table 1 Characteristics of the HCV viraemic positive participants

\begin{tabular}{lllll}
\hline Sequence ID & Gender & Genotype & Subtype & Accession Number \\
\hline LB_1 & Male & 5 & $5 a$ & MK392625 \\
LB_2 & Female & 5 & $5 a$ & MK392626 \\
LB_3 & Female & 5 & $5 a$ & MK392627 \\
LB_4 & Male & 5 & $5 a$ & MK392628 \\
LB_5 & Female & 4 & $4 \mathrm{v}$ & MK392629 \\
LB_6 & Female & 4 & $4 \mathrm{v}$ & MK392630
\end{tabular}

true mutations. Sequences were submitted to National Center for Biotechnology Information (NCBI) GenBank under accession numbers MK392625 to MK392630. Statistical analysis was performed using $\mathrm{R}$ version 3.6.0 [15].

\section{Results}

Study participants were Batswana adults and $63.3 \%$ were female. The age ranged from 16 years to 74 years with a median of 44 years and an interquartile range (IQR) of $32-55$ years. From the 55 participant samples we had access to, $6(10.9 \%)$ of those were RNA positive as shown in Table 1. The six participants had ages, ranging from 24 to 70 years with a median of 55.5 years as shown in Fig. 1a, and HCV was observed in older males and middle-aged women as shown in Fig. $1 \mathrm{~b}$.

Sequence analysis of 6 partial core regions revealed that four of the Botswana sequences belong to genotype $5 \mathrm{a}$, as shown by the clustering with other genotype $5 \mathrm{a}$ strains from South Africa, Ethiopia, and Denmark. Two Botswana strains belong to genotype $4 \mathrm{v}$ as shown by the clustering pattern with other genotype $4 \mathrm{v}$ strains from Ethiopia, Cyprus, and the United Kingdom as shown in Fig. 2.

Further analysis was performed to identify core mutations within the viral sequences as shown in Table 2.

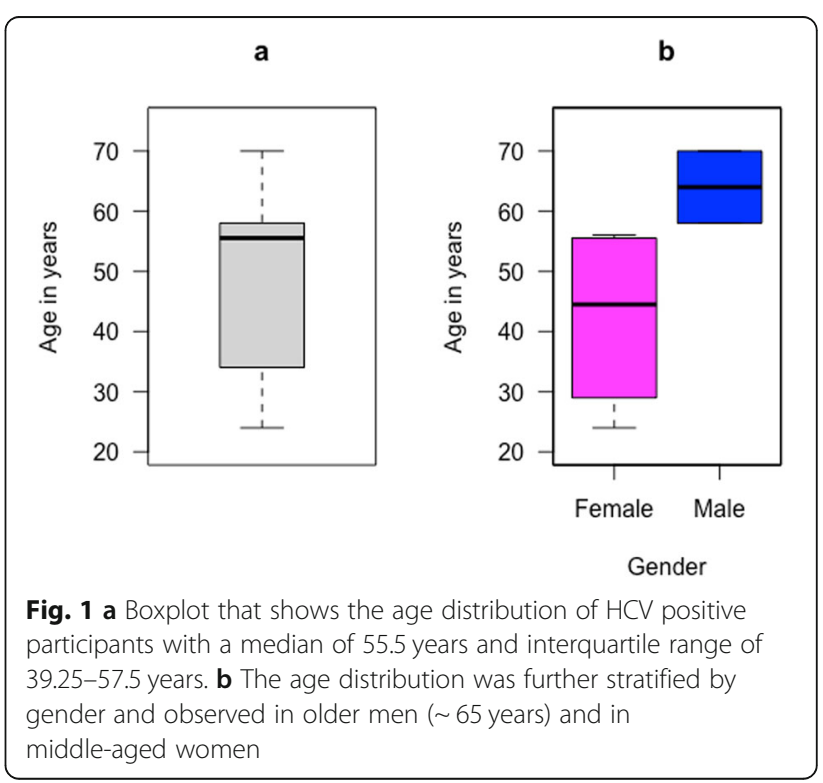




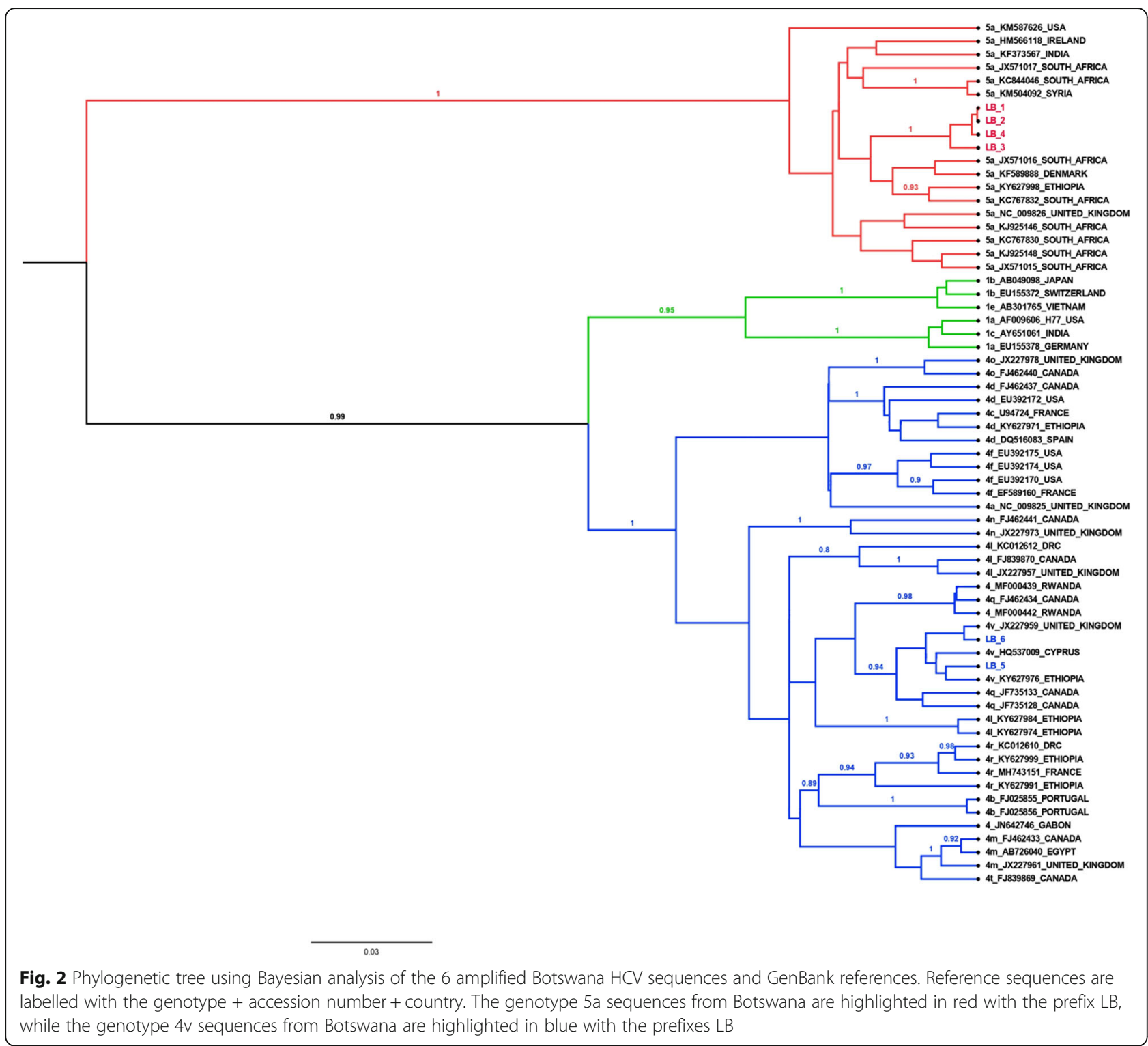

Most mutations were observed in genotype 5 samples (R9T, K10Q, T15I, L36 V and R70Q). Only one mutation (G95E) was observed in genotype 4.

\section{Discussion}

This is the first report on the circulating HCV genotypes from Botswana. The finding of genotypes $5 \mathrm{a}$ and $4 \mathrm{v}$ agrees with previously reported data from southern Africa [5, 26, 27]. Interestingly, genotype $4 \mathrm{v}$ has not been observed previously in southern Africa, although other genotypes, such as $4 \mathrm{c}, 4 \mathrm{~g}, 4 \mathrm{k}, 4 \mathrm{q}$ and $4 \mathrm{r}$, have been reported $[28,29]$. Genotype $4 \mathrm{v}$ has been reported in central Africa and the Middle East. In two studies, genotype $4 \mathrm{v}$ was observed in Rwanda and Ethiopia [30, 31]. To achieve elimination of HCV by 2030, DAAs should be introduced and administered to patients as per genotype
[10]. According to the observed genotypes, Botswana will need to procure Ledipasvir, Daclatasvir and Sofosbuvir as the DAA regimens recommended to treat genotypes 4 and 5 for patients with and without liver cirrhosis [10]. In this study, the HCV diversity in Botswana is low as compared to South Africa, since only two subtypes were observed. This observation could be due to small sample size and/or varying transmission dynamics.

In the current study the core gene was amplified as the region of interest, despite the recommended NS5B region for $\mathrm{HCV}$ genotype classification [32]. We selected a significant fragment of the core region to classify the $\mathrm{HCV}$ isolates, which also includes (but is not limited to) putative HCC core related mutations, since the core region has higher amplification rates compared to the NS5B region as previously reported [12]. 
Table 2 Core mutations observed in Botswana sequences and their association with disease progression and/or therapeutic response

\begin{tabular}{lllll}
\hline Mutation & Genotype & $\begin{array}{l}\text { Mutation } \\
\text { frequency }\end{array}$ & Clinical relevance & Reference \\
\hline G95E & $4 \mathrm{v}$ & 1 & Not characterized & {$[16]$} \\
R9T & $5 a$ & 4 & Not characterized & {$[17]$} \\
K10Q & $5 a$ & 4 & Increased risk of HCC & {$[18]$} \\
T15I & $5 a$ & 4 & Not characterized & {$[19,20]$} \\
L36V & $5 a$ & 1 & Not characterized & {$[21]$} \\
R70Q & $5 a$ & 4 & Increased risk of HCC + & {$[17,22$,} \\
& & & poor response to IFN & $23-25]$ \\
\hline
\end{tabular}

Abbreviations: HCC Hepatocellular carcinoma, IFN Interferon

The core mutations in genotype $5 \mathrm{a}-\mathrm{R} 9 \mathrm{~T}, \mathrm{~K} 10 \mathrm{Q}$, T15I, L36 Vand R70Q - account for most of the observed mutations. The K10Q mutation is associated with increased risk of HCC [18]. This mutation was the nucleotide substitution A28C in the core gene bringing about an amino acid substitution from lysine to glutamine. Further analysis from 100 genotype 5 sequences downloaded from the GenBank showed that only $5 \%$ of these references contained the $\mathrm{K} 10 \mathrm{Q}$ mutation. Interestingly, all four genotype 5 samples from the Botswana sequences had that mutation.

Several studies in genotype 1 strains have indicated that the R70Q mutation increases the risk of HCC due to its oncogenic effect $[18,23-25]$ and also confers resistance to IFN-based treatments [22]. This mutation occurs due to nucleotide substitution G209A resulting in an amino acid change from arginine to glutamine [18]. From the analysis with the GenBank genotype 5 sequences, it was interesting to note that $81 \%$ of the references contained the R70Q mutation compared to $16 \%$ with the wildtype amino acid. In a study conducted in South Africa, the R70Q mutation was observed in $90 \%$ of genotype 5a blood donors [33]. Whether the impact of this mutation in genotype 1 strains is the same in genotype 5 remains unclear. Presence of this mutation in only genotype 5 isolates could either be due to transmission of a mutated strain or a naturally occurring drug resistant mutation to the SOC [33]. However, the latter assumption cannot be confirmed since there are no data on duration of treatment. Despite the scarce data on impact of this mutation in genotype 5 , all four genotype 5 individuals may have a poor response to the current SOC. Thus, DAA regimens may improve treatment of individuals infected with $\mathrm{HCV}$ strains harbouring these mutations.

Only one mutation - G95E - was observed in one genotype $4 \mathrm{v}$ sample. However, this mutation has not been well characterized or associated with altering viral fitness or drug sensitivity. Most reported mutation analyses have been conducted on genotype 1 strains [20]. Therefore, more longitudinal studies in mutation analysis based on other genotypes, such as 4 and 5 , are warranted, as mutations differ by genotype.

A major limitation of the study was the modest population size evaluated and the low amplification success rate; therefore, there was a limited number of positive samples available for analysis. Furthermore, as no $\mathrm{HCV}$ antigen enzyme-linked immunosorbent assay (ELISA) was conducted due to low sample volumes, the low amplification rate may reflect a low proportion of current $\mathrm{HCV}$ infections versus seropositive but resolved infections. The low amplification rate may also be due to multiple freeze-thaw cycles for sample use in other studies prior to the current analysis. The cross-sectional nature of this study made following up on the patients with HCC-risk factors impossible. Therefore, we could not observe the oncogenic effect of the reported mutations in genotype 5 patients.

\section{Conclusion}

In summary, genotypes $5 \mathrm{a}$ and $4 \mathrm{v}$ are the circulating genotypes in Botswana. The mutations observed in this study confer resistance to the SOC, and, as per WHO recommendations, there is a need to introduce DAAs as the new SOC for Botswana in order to achieve elimination of HCV by 2030. The DAAs for Botswana HCV patients should include Ledipasvir, Daclatasvir and Sofosbuvir. A longitudinal study with a larger representative population is warranted to develop more understanding of the HCV epidemiology in Botswana.

\section{Abbreviations}

DAA: Direct acting antivirals; DNA: Deoxyribose nucleic acid; ELISA: Enzymelinked immunosorbent assay; HBV: Hepatitis B virus; HCC: Hepatocellular carcinoma; HCV: Hepatitis C virus; HIV: Human immune-deficiency virus; IFNa: Interferon -alpha; IQR: Interquartile range; MCMC: Markov chain Monte

Carlo; NCBI: National Center for Biotechnology Information; RNA: Ribonucleic acid; RT-PCR: Reverse transcriptase polymerase chain reaction; SOC: Standard of care; SVR: Sustained virologic response; WHO: World health organisation

\section{Acknowledgements}

The authors would like to acknowledge the study participants. We also acknowledge the University of Botswana, Princess Marina Hospital, National University of Science and Technology in Zimbabwe and the Botswana Harvard AIDS Institute Partnership for their support and contributions to the study.

\section{Authors' contributions}

LB, MA, SS, SG, SM and WTC conceived and designed the experiments. LB, CCB, SS, ZMS, SM, TM, BBP, PM and WTC conducted the experiments. LB, WTC, JTB, MA, SM and SG analysed the results. EZ, RMM, ME, SG and JTB provided expert review of the manuscript. All authors contributed to the writing and reviewing of the manuscript. All authors reviewed and approved the final manuscript.

\section{Funding}

MA, WTG, SM and SG were funded by the Sub-Saharan African Network for TB/HIV Research Excellence (SANTHE), a DELTAS Africa Initiative [grant \# DEL15-006]. The DELTAS Africa Initiative is an independent funding scheme of the African Academy of Sciences (AAS)'s Alliance for Accelerating Excellence in Science in Africa (AESA) and supported by the New Partnership for Africa's Development Planning and Coordinating Agency (NEPAD Agency) with funding from the Wellcome Trust [grant \# 107752/Z/15/Z] and the UK government. The views expressed in this publication are those of the author(s) 
and not necessarily those of AAS, NEPAD Agency, Wellcome Trust or the UK government. SM was partially supported was supported by the Fogarty International Center and National Institute of Mental Health, of the National Institutes of Health under Award Number D43 TW010543. The opinions, findings and conclusions expressed in this article are those of the authors and do not necessarily reflect the views of the sponsors.

\section{Availability of data and materials}

The datasets used to support the results of this study are available from the corresponding author upon request. Sequences are available in the National Center for Biotechnology Information (NCBI) GenBank under accession numbers MK392625 to MK392630.

\section{Ethics approval and consent to participate}

The study was approved by the Health Research and Development Committee (HRDC) at the Ministry of Health and Wellness (HPDME 13/18/1 X (897). Permission to access raw data was granted by the ethics committee of the university of Botswana and Princess Marina hospital. All participants consented prior to participation in the study.

\section{Consent for publication}

Not applicable.

\section{Competing interests}

$\mathrm{SM}$ is an editorial board member for BMC Infectious disease. The remaining authors declare no conflict of interest.

\section{Author details}

'Botswana Harvard AIDS Institute Partnership, Research Laboratory, Gaborone, Botswana. ²Department of Applied Biology and Biochemistry, National University of Science and Technology, Bulawayo, Zimbabwe. ${ }^{3}$ Department of Pathology, Faculty of Medicine, University of Botswana, Gaborone, Botswana. ${ }^{4}$ Department of Medical Laboratory Sciences, Faculty of Health Sciences, University of Botswana, Gaborone, Botswana. ${ }^{5}$ Department of Immunology and Infectious Diseases, Harvard T.H. Chan School of Public Health, Boston, MA, USA. ' University of Cincinnati College of Medicine, Cincinnati, $\mathrm{OH}$, USA.

Received: 10 July 2019 Accepted: 26 September 2019

Published online: 22 October 2019

\section{References}

1. Stanaway JD, Flaxman AD, Naghavi M, Fitzmaurice C, Vos T, Abubakar I, et al. The global burden of viral hepatitis from 1990 to 2013: findings from the global burden of disease study 2013. Lancet. 2016;388(10049):1081-8. https://doi.org/10.1016/S0140-6736(16)30579-7.

2. El-Zanaty F, Way A. Egypt demographic and health survey, 2008. In: Demographic and health survey (EDHS). Cairo: Ministry of Health and Population; 2009.

3. Razavi H, Waked I, Sarrazin C, Myers RP, Idilman R, Calinas F, et al. The present and future disease burden of hepatitis $\mathrm{C}$ virus $(\mathrm{HCV})$ infection with today's treatment paradigm. J Viral Hepat. 2014;21:34-59.

4. Agyeman AA, Ofori-Asenso R, Mprah A, Ashiagbor G. Epidemiology of hepatitis $C$ virus in Ghana: a systematic review and meta-analysis. BMC Infect Dis. 2016;16(1):391

5. Gower E, Estes C, Blach S, Razavi-Shearer K, Razavi H. Global epidemiology and genotype distribution of the hepatitis C virus infection. J Hepatol. 2014; 61(1):S45-57. https://doi.org/10.1016/j.jhep.2014.07.027.

6. Wester CW, Bussmann H, Moyo S, Avalos A, Gaolathe T, Ndwapi N, et al. Serological evidence of HIV-associated infection among HIV-1-infected adults in Botswana. Clin Infect Dis. 2006;43(12):1612-5.

7. Patel P, Davis S, Tolle M, Mabikwa V, Anabwani G. Prevalence of hepatitis B and hepatitis C coinfections in an adult HIV centre population in Gaborone, Botswana. Am J Trop Med Hyg. 2011;85(2):390-4. https://doi.org/10.4269/ ajtmh.2011.10-0510.

8. Choga WT, Anderson M, Zumbika E, Moyo S, Mbangiwa T, Phinius BB, Melamu P, Kayembe MK, Kasvosve I, Sebunya TK, Blackard JT, Essex M, Musonda RM, Gaseitsiwe S. Molecular characterization of hepatitis B virus in blood donors in Botswana. Virus Genes. 2018. https://doi.org/10.1007/ s11262-018-1610-z.
9. Van der Meer AJ. Value anti-hepatitis C virus therapy by its clinical efficacy. Hepatology. 2015;62:334-6.

10. WHO. Global hepatitis report. 2017. Available online: https://www.who.int/ hepatitis/publications/global-hepatitis-report2017/en/. Accessed 8 Oct 2018.

11. Lole KS, Jha JA, Shrotri SP, Tandon BN, Prasad VGM, Arankalle VA. Comparison of hepatitis $C$ virus genotyping by $5 \mathrm{~J}$ noncoding region- and core-based reverse transcriptase PCR assay with sequencing and use of the assay for determining subtype distribution in India. J Clin Microbiol. 2003;41(11):5240-4.

12. Cai Q, Zhao Z, Liu Y, Shao X, Gao Z. Comparison of three different HCV genotyping methods: Core, NS5B sequence analysis and line probe assay. Int J Mol Med. 2013;31:347-52. https://doi.org/10.3892/ijmm.2012.1209.

13. Kuiken C, Combet C, Bukh J, Shin-I T, Deleage G, Mizokami M, et al. A comprehensive system for consistent numbering of HCV sequences, proteins and epitopes. Hepatology. 2006;44(5):1355-61. https://doi.org/10.1002/hep.21377.

14. Drummond AJ, Suchard MA, Xie D, Rambaut A. Bayesian phylogenetics with BEAUti and the BEAST 1.7. Mol Biol Evol. 2012;29:1969-73.

15. R Core Team (2019). R: A language and environment for statistical computing. R Foundation for Statistical Computing, Vienna, Austria. https:// www.R-project.org/.

16. Zhang J, Yamada O, Ito T, Akiyama M, Hashimoto Y, Yoshida H, et al. A single nucleotide insertion in the $5^{\prime}$-untranslated region of hepatitis $C$ virus leads to enhanced cap-independent translation. Virology. 1999;261(2):26370. https://doi.org/10.1006/viro.1999.9879.

17. Sugiyama K, Suzuki K, Nakazawa T, Funami K, Hishiki T, Ogawa K, et al. Genetic analysis of hepatitis $C$ virus with defective genome and its infectivity in vitro. J Virol. 2009;83(13):6922-8. https://doi.org/10.1128/JVI.02674-08.

18. Hu Z, Muroyama R, Kowatari N, Chang J, Omata M, Kato N. Characteristic mutations in hepatitis $C$ virus core gene related to the occurrence of hepatocellular carcinoma. Cancer Sci. 2009;100(12):2465-8.

19. Kuntzen T, Timm J, Berical A, Lennon N, Berlin AM, Young SK, et al. Naturally occurring dominant resistance mutations to hepatitis $C$ virus protease and polymerase inhibitors in treatment-naïve patients. Hepatology. 2008;48(6): 1769-78. https://doi.org/10.1002/hep.22549.

20. Bull RA, Eltahla AA, Rodrigo C, Koekkoek SM, Walker M, Pirozyan MR, Luciani F. A method for near full-length amplification and sequencing for six hepatitis C virus genotypes. BMC Genomics. 2016;17(1):247.

21. Sakamoto M, Akahane Y, Tsuda F, Tanaka T, Woodfield DG, Okamoto H. Entire nucleotide sequence and characterization of a hepatitis $C$ virus of genotype V/3a. J Gen Virol. 1994;75(7):1761-8.

22. Akuta N, Suzuki F, Hirakawa M, Kawamura Y, Yatsuji H, Sezaki H, Suzuki Y, Hosaka T, Kobayashi M, Kobayashi M, Saitoh S, Arase Y, Ikeda K, Chayama K, Nakamura Y, Kumada $\mathrm{H}$. Amino acid substitution in hepatitis $\mathrm{C}$ virus core region and genetic variation near the interleukin $28 \mathrm{~B}$ gene predict viral response to telaprevir with peginterferon and ribavirin. Hepatology. 2010;52:421-9.

23. Nakamoto S, Imazeki F, Fukai K, Fujiwara K, Arai M, Kanda T, Yonemitsu Y, Yokosuka O, Nakamoto S, Imazeki F, Fukai K, Fujiwara K, Arai M, Kanda T, Yonemitsu Y, Yokosuka O. Association between mutations in the core region of hepatitis $C$ virus genotype 1 and hepatocellular carcinoma development. J Hepatol. 2010;52(1):72-8 Erratum in: J Hepatol, 52(4):620.

24. Fishman SL, Factor SH, Balestrieri C, Fan X, Dibisceglie AM, Desai SM, Benson $\mathrm{G}$, Branch AD. Mutations in the hepatitis $C$ virus core gene are associated with advanced liver disease and hepatocellular carcinoma. Clin Cancer Res. 2009;15(9):3205-13.

25. El-Shamy A, Eng FJ, Doyle EH, Klepper AL, Sun X, Sangiovanni A, lavarone M, Colombo M, Schwartz RE, Hoshinda Y, Branch AD. A cell culture system for distinguishing hepatitis $C$ viruses with or without liver cancer-related mutations in the viral core gene. J Hepatol. 2015. https://doi.org/10.1016/j. jhep.2015.07.024.

26. Petruzziello A, Marigliano S, Loquercio G, Cozzolino A, Cacciapuoti C. Global epidemiology of hepatitis $C$ virus infection: an up-date of the distribution and circulation of hepatitis C virus genotypes. World J Gastroenterol. 2016; 22(34):7824-40. https://doi.org/10.3748/wjg.v22.i34.7824.

27. Gededzha MP, Selabe SG, Blackard JT, Kyaw T, Mphahlele MJ. Near full-length genome analysis of HCV genotype 5 strains from South Africa. Infect Genet Evol. 2014;21(November):118-23. https://doi.org/10.1016/j.meegid.2013.10.022.

28. Gededzha MP, Selabe SG, Kyaw T, Rakgole JN, Blackard JT, Mphahlele MJ. Introduction of new subtypes and variants of hepatitis $C$ virus genotype 4 in South Africa. J Med Virol. 2012;84:601-7. https://doi.org/10.1002/jmv.23215.

29. Gededzha MP, Selabe SG, Kyaw T, Rakgole JN, Blackard JT, Mphahlele MJ. Introduction of new subtypes and variants of hepatitis $C$ virus genotype 4 in South Africa. J Med Virol. 2012;84(4):601-7. 
30. Iles JC, Raghwani J, Harrison GL, Pepin J, Djoko CF, Tamoufe D, LeBreton M, Schneider BS, Fair JN, Tshala FM, Kayembe PK, Muyembe JJ, Edidi-Basepeo S, Wolfe ND, Simmonds P, Klenerman P, Pybus OG. Phylogeography and epidemic history of hepatitis C virus genotype 4 in Africa. Virology. 2014; 464-465:233-43.

31. Hundie GB, Raj VS, GebreMichael D, Pas SD, Haagmans BL. Genetic diversity of hepatitis C virus in Ethiopia. PLoS One. 2017;12(6):0179064.

32. Quer J, Gregori J, Rodríguez-Frias F, Buti M, Madejon A, Perez-del-Pulgar S, Garcia-Cehic D, Casillas R, Blasi M, Homs M, Tabernero D, Alvarez-Tejado M, Muñoz JM, Cubero M, Caballero A, delCampo JA, Domingo E, Belmonte I, Nieto L, Lens S, Muñoz-de-Rueda P, Sanz-Cameno P, Sauleda S, Bes M, Gomez J, Briones C, Perales C, Sheldon J, Castells L, Viladomiu L, Salmeron J, Ruiz-Extremera A, Quiles-Pérez R, Moreno-Otero R, López-Rodríguez R, Allende H, Romero-Gómez M, Guardia J, Esteban R, Garcia-Samaniego J, Forns X, Esteban Jl. High- resolution hepatitis C virus subtyping using NS5B deep sequencing and phylogeny, an alternative to current methods. J Clin Microbiol. 2015:53:219-26. https://doi.org/10.1128/JCM.02093-14.

33. Prabdial-Sing N, Blackard JT, Puren AJ, Mahomed A, Abuelhassan W, Mahlangu J, Vermeulen M, Bowyer SM. Naturally occurring resistance mutations within the core and NS5B regions in hepatitis C genotypes, particularly genotype 5a, in South Africa. Antivir Res. 2016;127:90-8.

\section{Publisher's Note}

Springer Nature remains neutral with regard to jurisdictional claims in published maps and institutional affiliations.

Ready to submit your research? Choose BMC and benefit from:

- fast, convenient online submission

- thorough peer review by experienced researchers in your field

- rapid publication on acceptance

- support for research data, including large and complex data types

- gold Open Access which fosters wider collaboration and increased citations

- maximum visibility for your research: over $100 \mathrm{M}$ website views per year

At $\mathrm{BMC}$, research is always in progress.

Learn more biomedcentral.com/submissions 